Journal of Educational Technology

\& Online Learning

Volume 3 | Issue 1 | 2020

http://dergipark.gov.tr/jetol

\title{
Successful implementation of E-learning in self-financed Higher Education: Experience from Hong Kong
}

Emily $\mathrm{Ng}$

emily.ng@hkuspace.hku.hk; The Hong Kong University School of Professional and Continuing Education Community College; Hong Kong; ORCID:0000-0002-4725-9752

Doi: $10.31681 /$ jetol.655496

Suggested citation: Ng, E. (2020). Successful implementation of E-learning in self-financed Higher Education: Experience from Hong Kong. Journal of Educational Technology \& Online Learning, 3(1), 91-107.

\begin{tabular}{l} 
Article Info \\
\hline Received : 05.11 .2019 \\
Revised : 29.11 .2019 \\
Accepted: 18.12 .2019 \\
\hline
\end{tabular}

\begin{abstract}
Digital technologies can reinvent the higher education in $21^{\text {st }}$ century. E-learning introduces change to both the people and the organization on any scale. To keep abreast of the times and making learning fun, one of the self-financed Higher Education Sector in Hong Kong introduced Virtual Reality (VR) and online learning for aviation and healthcare courses. This paper explores the successful implementation of E-learning in a Higher Education sector in Hong Kong. The paper investigates the constraints which affect the successful implementation of E-learning in the sector. It also provides some strategies for academicians in development and implementation of Elearning. Educational leaders can strategically promote and enable E-learning at organizational and individual levels by using Peter Senge's Five Disciplines of Learning Organization (1990). The keys to achieve a learning organization are personal mastery, mental model, shared vision, team learning and system thinking. These five disciplines support and sharpen one another, integrated by systems thinking.
\end{abstract}

Keywords: elearning, pedagogy, implementation of elearning, learning, school management, learning organization

\section{INTRODUCTION}

The invention of the computer and the internet has brought tremendous educational change over the last century. Emerging educational innovations and methods, such as MOOC, Blended Learning and Virtual Reality, are radically transforming teaching and learning in higher education. To keep abreast of the times and making learning fun, one of the self-financed Higher Education sector introduced Virtual Reality (VR) and online learning for aviation and healthcare courses. The developed VR contents and online learning break the limitations of time and space, and helps students to reach areas where field study is impossible. The purpose of this paper is to address how the educational leaders can strategically promote and enable Elearning at organizational and individual levels by applying Peter Senge's Five Disciplines of Learning Organization (1990). The five disciplines including personal mastery, mental models, 
shared vision, team learning and systems thinking are applied to critically analyze this change of E-learning pedagogies. The challenges and strategies for E-learning implementation will be discussed in the following paragraph.

\section{BACKGROUND}

The rapid change of technology has a significant impact on teaching and learning. The emergence of online learning to replace or to supplement face-to-face learning will come naturally. All educational sectors around the globe are seeking viable, blended and sustainable modes of online courses (e.g. MOOC, SPOC). One of the self-financed Higher Education sector endeavors to develop E-learning and build up the capability of offering online courses and VR contents. Senge (1990) defines learning organization as a place where people continually expand their capacity to create the results they truly desire, and where people are continually learning how to learn together. The learning disabilities in an organization can be fatal and the emergence of learning organization requires the climate created by five disciplines. Many studies indicated that the educational leaders always encounter many challenges in the Elearning implementation (Shahmoradi et al., 2018; Tarus et al., 2015; Muresan, \& Gogu, 2013; Alias et al., 2012). Lack of training, poor awareness programme, poor infrastructure, poor preparation of the academicians and students to use of E-learning and their negative perception are the contributing factors of the failure of the E-learning (Zulfiqar et al., 2018; Shahmoradi et al., 2018; Naziyabanu, et al., 2017). Reshaping the perceptions by academicians and students might also contribute to the success of E-learning implementation (Rodrigues et al., 2019; Shahmoradi et al., 2018). The paper would demonstrate an example of how educational leaders can successfully implement E-learning at organizational and individual levels by applying Peter Senge's Five Disciplines of Learning Organization (1990). The paper may contribute to knowledge around E-learning implementation in a self-financed Higher Education in order to enhance educational practice.

\section{DISCUSSION}

\section{The Learning Disabilities}

Four constraints have the potential to hamper or hinder the E-learning plan in the institution These include: 
1. "I am my position" - employees focus only on their position instead of what value they add to the organization goal. Teachers primarily concern they are already overtaxed with current work responsibilities and are not willing to develop new E-learning pedagogies.

2. "The enemy is out there" - when things go wrong, employees blame others rather than examining the root cause of the problem. Staff who are uncomfortable with E-learning may get embarrassment over the difficulty of trying new things. Those with low digital literacy may feel foolish trying to the assistance they need. Fear of going wrong and blame inhibit their leaning.

3. "The parable of the boiling frog" - maladaptation to gradually building threats. Tsunami is coming that will be wipe away any the school that does not adapt to the new technological reality (Patterson, 2016). Online learning is a new and much less expensive technology for learning (Kasraie, \& Kasraie, 2010; Deming et al., 2015). In order to survive, higher education will have to come to grips with new technology or risk of obsolescence (Davidson, \& Goldberg, 2010). It is problematic when teachers who get used to more traditional classroom approaches may not recognize E-learning is a trend in global educational sectors. In the meantime, they may not align with the school's vision of becoming an internationally recognized the school for high-quality E-learning development. As a result, they are not ready to build up their capabilities in online courses to make the school sustainable in the fast-technological changing environment.

4. "The fixation on events" - people's thinking is dominated by short-term events instead of focus on small continue improvement. Teachers who having conceptual ties to a traditional paradigm which is textbook-based and classroom-based will more resist to change. As a result, teachers may not cohere with the school's aspiration to enhance expansion of new online learning models and approaches (e.g. MOOC, blend mode) suitable for adaptation to the different learning needs of students in different places, like Mainland China and the region.

\section{The Five Learning Disciplines}

\section{Personal mastery}

Technology has altered the educational landscapes so much that the entire of learning is changing at an unheard of pace (Fok, 2012; Miller \& Doering, 2014). Nevertheless, the educational leaders cannot focus solely on technology. At the same time, the leaders have to give equal energy to create a learning culture. Personal mastery implies the employees 
continually clarify and deepen personal vision which expand the shared vision through selfunderstanding, and personal growth (Senge, 1990). Learning organization exists through individual learning. For organization management, the active force is people (Bailey, 2018). Leaders cannot force staff to embark on the path of personal growth. Leaders can foster personal mastery by creating a conducive climate and being a role model by committing to their own personal mastery.

\section{Creating a conducive climate}

The school's organizational climate will improve personal mastery in three ways. First, learn every day on the job (Fullan, 2008). E-learning Committee establishes the E-learning culture which initiate academicians to engage in E-learning and support staff to use technology in teaching and learning. Along with basic infrastructure such as network, the important element E-learning system such as Intranet, SharePoint, learning portal and Moodle learning management system is established. It aims to integrate E-learning in employees' careers and make learning directly into everyday work. This is where employees get the reinforcement. With a well-supported system, employees are encouraged to use Net resource and share knowledge. The daily working activities actually involved in E-learning system, so the staff can understand it not from reading it but doing it. It thereby initiates technology being a part of daily work activities and gives them the incentive to enhance their knowledge in adopting technology.

Second, awareness actually drives the change (Parlakkilic, 2013). Through email, trainings and regular staff meetings, the school is spreading information that it is necessary for front-line teachers to establish a pedagogy which best leverages the power of technology to benefit student learning in the $21^{\text {st }}$ century. The school communicates the messages that we need to know about why we are moving to E-learning, why it is good for the school and the staff. Many data support that E-learning would become a main education trend in the future (Ebner \& Schiefner, 2010; Rodrigues, 2019; Glenn, 2014). The school facilitates staff to see current reality as it is and identify what is important to them. Personal vision means keying into what you want (Senge, 1990). With increased awareness of the need of moving to E-learning, staff could have a clear vision of how things should be. Academicians are motivated to engage in E-learning as they recognize they play a critical role in leading this ubiquitous, technologically-driven learning environment. 
However, a gap will exist between reality and personal vision that causes tension (Senge, 1990). Staff holding personal vision of E-learning development, may find the gap when their personal vision differs from realities that they have insufficient knowledge and skills of adopting Elearning. Creative tension can generate energy for change (Senge, 1990). Ultimately, staff are motivated to learn in active pursuit of continuous improvement and choose to take action. For example, increase digital competency to bring reality into line with the vision. This intrinsic desire to change is a cornerstone of personal mastery (Senge, 1990).

Third, the school creates an incentive for academics to continuously develop digital competency. E-Learning Committee conducts a range of training sessions with different level based on learner digital literacy and interest. It includes Web 2.0, VR content, mobile learning, Virtual Classroom and Webinar. These hand-on trainings have direct implication on employees' job and train the users practically, so employees are motivated to take it.

At the same time, learning experience that results in creating content. Trainings persuades users with a view to increase their digital literacy and so progressively shifting their attitudes towards positive direction. In order to make E-learning a success, cultural change is required about how training and learning starts and, more importantly, how it is delivered (Mitchell \& Honore, 2007). These trainings are designed to address specific learning goals such as increase employees' digital literacy and the awareness for the need of moving to E-learning. These interesting and interactive trainings make users find using the E-learning technology less of a chore and more like a discovery. Resistance to change can stem from personal discomfort (Oreg, 2018). According to Technology Acceptance Model (Venkatesh \& Davis, 2000), when people perceived ease to use and usefulness of E-learning technology, they would feel more comfortable to try new technology.

\section{Role-modeling}

Creating a learning culture requires absolute commitment from the top down (Senge, 1990). Management must communicate and demonstrate its commitment to the learning culture (Senge et al., 2011). The senior management and programme managers are accountable for learning, being selfless or sacrifice for leading the teaching team to manage E-learning. First, they lead by example. The role of academics as teachers as become multifaceted. They see themselves not just a teacher but an innovator to exploit the potential of the E-learning. They demonstrate a high level of participation and enthusiastic commitment in the training sessions and E-learning development. They initiate E-learning in curriculum planning, VR content and online materials. 
At the same time, they guide the junior teaching staff through their learning quest and connect them with ideas of willingness to continuous learning and professional development. In this way, the enthusiasm and energy are palpable. When each member of organization gets a genuine sense of commitment to how the team work as a whole, not just for doing the job, no more "I am my position". The team could work in an extraordinary way and create a shared vision of pushing E-learning forward that align with whole the school's developments.

Second, leaders cannot build a learning culture by making it mandatory (Senge, 2012). Employees may feel disrespected when assigned training courses, leading to passive learning (Kim, Kim, \& Lee, 2015). The school leaders always emphasize learning is not in top-manner but learner-centered. The academicians are seriously encouraged to complete some E-learning training courses per year in each individual development plan. Voluntary learning echoed with their impulses to learn and expand their capabilities, at their hearts. It empowers them to move learning from passive to a level of engagement or participation.

\section{Mental models}

Mental models describe the ingrained assumptions and generalizations people have which influence their action (Senge, 1990). Transforming mental model expands individual capacity to create change.

\section{Reflecting the staff mental model}

Having people change their mental models is to have people reflect on their own beliefs (Senge, 1990). Surfacing the staff mental model makes them recognize any resistance to change in our mind. Apart from digital competency enhancement, E-learning Committee conducts workshops on E-learning pedagogical training in order to reflect their belief towards E-learning and improve the actions and decisions that shape school's vision.

In the workshops, the academicians discuss any resistance factors and share situations experienced as difficult in E-learning development in a small group. In this exercise, employees explore their mental models. This mode of inquiry helps people to expose the hidden assumptions (Senge, 1994). The assumptions that underline their practices is examined. Many academicians take non-traditional classroom learning as less effective and less valuable and thus they do not initiate E-learning.

With case studies of E-learning implementations in branch campuses and other organizations, academicians are encouraged to use reflective thinking and self-analysis on how E-learning 
differs from traditional learning and what are the costs and benefits of E-learning. The aviation course is a good example. VR simulates various emergency such as in-flight fires and emergency landings for students to execute the emergency procedure in small team. VR technology brings students more sensational learning experience which is impossible on the traditional classroom and textbook-based learning. In this case, E-learning undoubtedly could enhance the teaching process and student learning experience.

With effective use of E-learning technology can increase teacher productivity (RadovićMarković, 2010; Rodrigues et al., 2011; Vargas, 2013; Ngai et al., 2018), reduce workload (Selwood, \& Pilkington, 2005) and save cost (Cushard, 2017). Change will happen when value is transformed (Stacey, 2007). Transforming the staff mental models can help them to identify new way of thinking towards E-learning. The chance of success of E-learning absolutely depends on the acceptance and execution of required-change in the thinking and behavior of the users (Parlakkilic, 2013). Staff resist change in the face of uncertain future benefits (Oreg, 2018). When staff recognize the benefits of E-learning it brings to them, students and organization, they could transform the perceptions of E-learning and eventually change to adopt E-learning so the school can keep pace.

\section{Overcome resistance to change}

Most academicians acknowledge the significance of E-learning, but they seldom practice it (Thieman, 2008). There is a gap between perception and practice. Change requires moving from the known to the unknown (Cummings \& Worley, 2001). E-learning introduces a shift in culture and habits, resistance to E-learning originates mainly from a fear of risk (Ortiz, 2012; Parlakkilic, 2013). As mentioned before, staff always fear of going wrong and blame. If the abovementioned conducive climate is created, staff resistance can be transformed into collaborative learning workplace (Douglas et al, 2017).

The school has to accept the resistance as part of the process and be prepared to deal with it (Sherratt, 2017). Communication, leadership, empathy and support are the strategies for dealing with resistance to change (Cummings \& Worley, 2001; Hon et al., 2014). The school develops no blaming culture which is important to provide support and empower employees to embrace change (Sahni, \& Kumar, 2012). The working environment should be safe where honest mistakes are forgiven. Staff are initiated to change when they think the organization where it is safe for teachers to create visions and accepts challenge the status quo. Empowering leadership 
fosters a trust-build relationship and promotes employees' sense of autonomy which help reduce the resistance to change (Hon et al., 2014)).

The school has to see the situation from employees' perspective and shows empathy and support to allay unfounded fears. Understanding how employees are experiencing change is the first step to overcoming resistance (Sherratt, 2017). Regular meetings with all stakeholders are arranged in order to actively listen their value of E-learning, understand their constraints, exchange ideas and provide supports. Resistance is lower the greater are feeling of security (Kunze et al., 2013; Oreg, 2018).

At the same time, employees will be more willing to share their concerns and fears when they feel that the management are genuinely interested on their feeling. This provides practical information about resistance as well as lay the foundation for the kind of joint problem solving required to overcome the constraints (Cummings \& Worley, 2001).

In addition, leaders may place employees with higher levels of dispositional resistance on supportive working groups which are provided both tangible (e.g. extra guidance) and psychological (a sense of security from a supportive safety net) support. Leaders also encourage knowledge sharing and contribution to benefit from the buffering effects of coworker support. Learning community facilitates teacher change (Tam, 2015). This community could support those employees with limited experience of E-learning implementation and little-known technologies to overcome resistance.

\section{Shared vision}

Individuals require the skills of personal mastery and mental modeling, whereas an organization has to work to promote a shared vision to its employees. With a shared vision, the members of the organization have a common goal for the organization (Senge, 1990). A common goal is enormously significant for the organization as it gives the direction and energy for learning.

\section{Unearthing shared picture of the future}

Information and transparency are central to the success of change (Lozano, 2013). Effective communication about the change can help staff realistically for change (Cummings \& Worley, 2001). The senior management provide a diversity of information of E-learning development and unearth shared picture of the future. First, the declining student demographics in coming years will certainly pose challenge to the school, and keen competition among self-financed 
High Education institutions is expected. It is inevitable to see further reduction in number of programmes and staff in the school to commensurate with the declining local student enrollment.

Second, the school's vision is to become an internationally recognized institution for highquality E-learning development. University Grants Commission (2016) published a blueprint document which echoed the school's vision of promoting E-learning. Third, the significant effects of innovation and the associated ideological change on pedagogy urge academicians to rethink the E-learning pedagogy in $21^{\text {st }}$ century.

The senior management makes a regularly deep dialogue with all staff to encourage them to pursue the common goal of developing and expanding E-learning such as providing online courses to Hong Kong, the Mainland and overseas in order to make school sustainable in coming years. At the same time, the global educational sectors are seeking viable, blended and sustainable modes of online courses. The crux of the matter is speed and mode. The school is responding by building up the capability of offering online courses. In the past, some MOOCs were established. The school measures the effectiveness and provides support over time. In a long-term goal, at least a certain portion of the school's course should be in some form of online mode.

By providing staff with a common goal and compelling reason for why change is necessary and worth the effort, the vision can energize commitment to change (Senge, 1994). Staff more committed when they know they are required to achieve the school goals in expected timeline. Most importantly, in order to survive, employees would have to change with times and transform themselves. Employees would have to be readily take it upon themselves to build competencies and gain new skill in the new era of E-learning.

Through skillful discussion, the school manages to bind staff together around a common identity. The senior management emphasizes when all levels of organization share the same vision of high-quality of E-learning development and consequently the school is confident in meeting these challenges and will continue to provide high quality of education. This shared vision fosters staff to have a genuine commitment and enrollment rather than compliance. The aim is to win the hearts and minds of people (Mathews, \& Linski, 2016). To succeed, all levels of the organization do positive things towards achieving common goals instead of they are told to do. Beyond the digital competency enhancement, staff are highly motivated to develop E- 
learning in order to drive towards a shared goal of making the school sustainable in this challenging environment.

\section{Support from the top}

The school does not simply announce the start of the initiative. Instead, make it clear that the management supports the programme, this will increase employees' buy-in and thus participation in the achievement of the goal. First, the school provides resources, for example, sufficient funding is invested for staff training and VR contents and teaching facilities as well as a VR lab has be launched in 2019. Second, the school has hired IT coordinators to support teachers to use of E-learning effectively across the curriculum. Employees are always occupied with their current work responsibilities and when they encounter technical problems, immediate help should be provided. That way, employees would be more likely to support E-learning. Third, learning must be easily available, actively encouraged, time must be available for it (Senge, 2012). In order to facilitate staff learning, the school provides the studying time, sponsorships and infrastructure. If staff are not provided time off during duty for trainings and are supposed to use their personal time, they may not proceed it. Last, the school has launched various strategies with focus on assisting teachers in drawing up and implementing E-learning in curriculum development. Staff piloting MOOCs are provided feedback on how they are doing and ongoing support.

According to change model (Hiatt, 2006), change involves awareness, desire, knowledge, ability and reinforcement. First, the school increases employees' awareness of the need for Elearning development and develops the staff personal mastery. Second, by surfacing and transforming the staff mental model to overcome the constraints, and hence a new way of thinking towards E-learning is created. With a clear and objective shared vision, staff could generate energy to participate and promote the change to drive towards common goals. Third, with the support from the school and adequate knowledge and skills acquired in the trainings, staff is able to implement E-learning. Last, the school gives reinforcement to staff to sustain the change post-implementation. Beyond the change at individual level, all team members have to understand their role in embracing change. 


\section{Team learning}

Team learning is the discipline by which personal mastery and shared vision are brought together (Senge, 1990). It establishes the skills of groups of people so as to get the larger picture that lies beyond individual perspectives.

\section{Collective intelligence}

Team members often interact and work with other teams, thus spreading the learning across teams (Senge, 1994). First, the new collaborations with different programme teams, including the development and results are shared via monthly E-learning newsletter. These newsletters demonstrate how some teachers have been utilizing the E-learning pedagogies and students enrich their learning experiences. Second, awards and recognition are granted to those academicians who are active using E-learning in their teaching and learning activities. The practice sharing of award recipients is published in the E-Learning newsletter and being announced to campus community.

Third, there are experience sharing videos and workshops, through which seconded teachers employed E-learning or attended E-learning conference will provide professional support to other teachers in promoting wider use of E-learning to enhance teaching and learning. In this way, leader act as a teacher. Participating employees can serve as teachers for their fellow employees. It helps team to see gaps, find the solutions, and experience a learning spirit. Fourth, there is a wealth of cases relating piloted E-learning pedagogies pooled by E-learning Committee, from which teachers may draw for experiences sharing or reference. Stories from employees are collected and used to create reality-based simulations and scenarios. Most importantly, the abovementioned learning community is created to give staff an avenue to gather input for developing E-learning content, support each other, swapping experiences, and best practice sharing. These supportive coworkers act as significant interrelated cues for shaping employees' creativity (Hon et al., 2014). By so doing, each team could cultivate the capacity of members to work together with other groups and team learn to think insightfully about complex issue of implementation of high-quality E-learning, using the ability of many minds working together outgun a single mind.

\section{Systems thinking}

System thinking integrates all five disciplines which are interconnected and interdependent (Senge, 1990). System thinking is the focus of learning organization where people continually 
expand their capacities to improve the organization as a whole. Leaders need insights into current reality as well as picture of future toward which they are moving. For example, if leaders only measure the outcomes such as the number of online programmes established whereas the learning culture is never created, it is more likely compliance for training and job complement rather than commitment occurs. Therefore, it stops improving the organization as a whole in long term.

Leaders have to look at it from a holistic viewpoint rather than small unrelated manageable parts (Senge, 1990). From a holistic viewpoint, working on change is not solely working on the content of change, nor solely on the organization of change, but also the personal dimensions of change (Morrison, 1998). If the employees themselves are not sufficiently motivated to align with the goal of the school, it is no use to the hardware provision.

System thinking is thinking the organization as a whole, as a system, where single components affect the other elements of the set (Senge, 1990). When entire members of organization felt valued about E-learning, developed the ultimate intrinsic desires to change and a shared vision to guide their work as well as engaged as team to learn and work together, the team would result in extraordinary productivity. That way, small changes can produce big result. It is vital to improve organization as whole. System thinking is leverage (Senge, 1994).

\section{CONCLUSION AND SUGGESTION}

Digital technologies can reinvent the higher education in $21^{\text {st }}$ century. E-learning introduces change to both the people and the organization on any scale. The educational leaders always encounter many challenges during the implementation of E-learning. In this paper, the constraints and strategies for E-learning are addressed. This paper also demonstrates how the educational leaders can strategically promote and enable E-learning at organizational and individual levels by using Peter Senge's Five Disciplines of Learning Organization (1990). The keys to achieve a learning organization are personal mastery, mental model, shared vision, team learning and system thinking. These five disciplines support and sharpen one another, integrated by systems thinking. When people execute the discipline of personal mastery, they experience progressive changes. The management cultivates personal mastery by creating a conducive climate including staff training and infrastructure as well as being a role model by demonstrating an enthusiastic commitment in E-learning development. Ultimately, employees build their capacities and intrinsic drive towards continuous improvement by learning. At the 
same time, employees are encouraged to examine their mental models and identify a new way of thinking towards E-learning through various trainings and dialogues with the management. When the constraints such as fear of risk are overcame, employees are more likely to dare to change. With shared vision, people can see how their actions contribute to changing and shaping their future. Employees share the common goal of providing high-quality E-leaning development in order to make the school sustainable in this challenging environment. With a common goal, they would add commitment in organization. All three disciplines develop the basis for team learning, which helps team members to create results they desire, at a level beyond their individual capability. The team members learn with each other to build their individual and collective intelligence. Systems thinking underlies all four other disciplines to help the staff see the big picture and their roles in it, and leverage in complex situations. The management focuses on the big picture instead of seeing mere sections. Effective communication, leadership and support is key to win the heart and mind of people as well as to engage with people to create the energy necessary to drive the change. The chance of success of E-learning would continuously increase with the crucial mass of organizational members who developed ultimate intrinsic desire to change and expand their capacities. Finally, the author believes teachers' love to students is the fundamental driving force to overcome all the resistance when E-learning is launched.

\footnotetext{
E-öğrenmenin kendini finanse eden yükseköğretimde başarılı bir şekilde uygulanması: Hong Kong deneyimi

Özet

21. yüzyılda dijital teknolojiler yüksek öğretimi yeniden yapılandırabilir. E-öğrenme hem bireysel hem de kurumsal anlamda dönüşüm gerektirmektedir. Zamanın gereklerine ayak uydurmak ve öğrenmeyi eğlenceli hale getirmek için Hong Kong'daki yüksek öğretim sektörlerinden biri, havacılık ve sağlık konuları ile ilgili derslerin öğretimi için çevrimiçi öğrenme ve sanal gerçeklik uygulamalarını tanıtmışlardır. Bu çalışmada Hong Kong'da yükssek öğretim seviyesinde uygulanan başarılı e-öğrenme uygulamalarını incelenmiştir. E-öğrenme uygulamalarından başarıyı etkileyen faktörler belirlenmeye çalışılmıştır. Ayrıca e-öğrenme içerikleri geliştiren ve uygulayan akademisyenler için faydalı stratejileri ortaya konulmuştur. Eğitim yöneticileri, Peter Senge'nin geliştirdiği öğrenme organizasyonları için beş disiplini (1990) temel alarak bireysel ve kurumsal olarak e-öğrenmeyi destekleyebilirler. Öğrenme organizasyonlarının başarılı olmasındaki anahtar kavramlar; kişisel uzmanlık, zihinsel model, ortak vizyon, takım öğrenmesi, sistemsel düşünme şeklinde sıralanabilir. Bu beş disiplin sistemsel düşünme ile entegre bir şekilde birbirlerini desteklemektedirler.
}

Anahtar kelimeler: e-öğrenme, pedagoji, e-öğrenmenin uygulanması, öğrenme, okul yönetimi, öğrenme organizasyonu 


\section{About the Author(s)}

\section{Emily Ng}

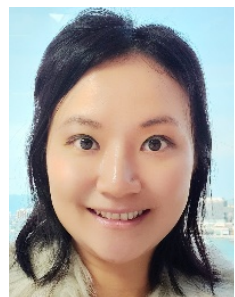

Emily Ng has got bachelor degree and master degree from the Chinese University of Hong Kong, Faculty of Medicine. She has been being a health care educator over a decade. Her teaching and research interests includes E-learning, pedagogy, student engagement and health care.

Mailing Address: The Hong Kong University School of Professional and Continuing Education Community College, 28, Wang Hoi Road, Kowloon Bay, Kowloon, Hong Kong.

E-mail: emily.ng@hkuspace.hku.hk

\section{REFERENCES}

\section{Article:}

Alias, N., Zakariah, Z., Ismail, N., \& Aziz, M. (2012). E-Learning Successful Elements for Higher Learning Institution in Malaysia. Procedia - Social and Behavioral Sciences, 67(C), 484-489.

Bailey, C. (2018). Strategic human resource management (2nd ed.). Oxford: Oxford University Press.

Cummings, T., \& Worley, C. (2001). Essentials of organization development and change. Australia: South-Western College Pub.

Cushard, B. (2017). More eLearning needed to improve sales enablement efforts: 3 benefits of eLearning. HMC Sales, Marketing and Alliances Excellence Essentials. Aurora.

Davidson, C., \& Goldberg, D. (2010). The future of thinking: Learning institutions in a digital age. Cambridge: MIT Press.

Deming, D. J., Goldin, C. F., Katz, L., \& Yuchtman, N. (2015). Can online learning bend the higher education cost curve? American Economic Review, 105(5), 496-501.

Douglas, J., Muturi, D., Douglas, A., \& Orchieng, J. (2017). The role of organizational climate in readiness for change to lean Six Sigma. The TQM Journal, 29(5), 666-676.

Ebner, M., \& Schiefner, M. (2010). Looking toward the future of technology-enhanced education: Ubiquitous learning and the digital native. Hershey PA: Information Science Reference.

Fok, W. (2012). The new era of e-learning: Mobile learning \& interactive class for the new curriculum. Hong Kong: University of Hong Kong.

Fullan, M. (2008). The six secrets of change: What the best leaders do to help their organizations survive and thrive (1st ed.). San Francisco: Jossey-Bass. 
Glenn, F. (2014). ELearning: Exploring digital futures in the 21st century. Education Sciences, 4(3), 209-212.

Hiatt, J. M. (2006). ADKAR: a model for change in business, government and our community. Prosci.

Hon, A., Bloom, M., \& Crant, J. (2014). Overcoming resistance to change and enhancing creative performance. Journal of Management, 40(3), 919-941.

Kasraie, N., \& Kasraie, E. (2010). Economies of eLearning in the 21st Century. Contemporary Issues in Education Research, 3(10), 57-62.

Kim, S., Kim, H., \& Lee, J. (2015). Employee self-concepts, voluntary learning behavior, and perceived employability. Journal of Managerial Psychology, 30(3), 264-279.

Kunze, F., Boehm, S., \& Bruch, H. (2013). Age, resistance to change, and job performance. Journal of Managerial Psychology, 28(7), 741-760.

Lozano, R. (2013). Are companies planning their organizational changes for corporate sustainability? An analysis of three case studies on resistance to Change and their Strategies to overcome it. Corporate Social Responsibility and Environmental Management, 20(5), 275-295.

Mathews, B., \& Linski, C. (2016). Shifting the paradigm: Reevaluating resistance to organizational change. Journal of Organizational Change Management, 29(6), 963-972.

Miller, C., \& Doering, A. (2014). The new landscape of mobile learning: Redesigning education in an app-based world. New York: Routledge.

Mitchell, A., \& Honore, S. (2007). Criteria for successful blended learning. Industrial and Commercial Training, 39(3), 143-149.

Morrison, K. (1998). Management theories for educational change. London: SAGE Publications.

Muresan, M., \& Gogu, E. (2013). E-learning Challenges and Provisions. Procedia - Social and Behavioral Sciences, 92(C), 600-605.

Naziyabanu, M. P., Armstrong, K. \& Solomon, M. (2017). Investigating Factors Influencing the Implementation of e-learning at Rural Based Universities. Information Technology Journal, 16 (3), 101-113.

Ngai, C., Lee, W., Ng, P., \& Wu, D. (2018). Innovating an integrated approach to collaborative eLearning practices in higher education: The case study of a corporate communication eplatform. Studies in Higher Education, 1-21. 
Oreg, S. (2018). Resistance to change and performance: Toward a more even-handed view of dispositional resistance. The Journal of Applied Behavioral Science, 54(1), 88-107.

Ortiz, C. (2012). The psychology of lean improvements: Why organizations must overcome resistance and change the culture. Boca Raton: CRC Press.

Parlakkilic, A. (2013). E-Learning change management: Challenges and opportunities. Turkish Online Journal of Distance Education, 14(4), 54-68.

Patterson, D. (2016). An interview with Stanford University president John Hennessy. Communications of the ACM, 59(3), 40-45.

Radović-Marković, M. (2010). Advantages and disadvantages of E-learning in comparison to traditional forms of learning. Annals of the University of Petroşani, Economics, 10(2), 289298.

Rodrigues, H., Almeida, F., Figueiredo, V., \& Lopes, S. (2019). Tracking e-learning through published papers: A systematic review. Computers \& Education, 136, 87-98.

Rodrigues, J., Sabino, F., \& Zhou, L. (2011). Enhancing e-learning experience with online social networks. IET Communications, 5(8), 1147-1154.

Sahni, S., \& Kumar, V. (2012). Can we blame the climate of an organization for the stress experienced by employees? Jindal Journal of Business Research, 1(2), 181-192.

Shahmoradi, L., Changizi, V., Mehraeen, E., Bashiri, A., Jannat, B., \& Hosseini, M. (2018). The challenges of E-learning system: Higher educational institutions perspective. Journal of Education and Health Promotion, 7(1), 116.

Selwood, I. \& Pilkington, R. (2005). Teacher workload: using ICT to release time to teach. Educational Review, 57(2), 163-174.

Senge, P. (1990). The fifth discipline: The art and practice of the learning organization. New York: Currency Doubleday.

Senge, P. (1994). The Fifth discipline fieldbook: Strategies and tools for building a learning organization. London: Nicholas Brealey Pub.

Senge, P. (2012). Schools that learn: A fifth discipline fieldbook for educators, parents and everyone who cares about education (1st rev. ed.). New York: Crown Business.

Senge, P., Kleiner, A., \& Roberts, C. (2011). Dance of Change: The challenges of sustaining momentum in learning organizations. London: Nicholas Brealey Publishing.

Sherratt, S. (2017). How to overcome resistance to change. Public Finance, (3), 44-45. 
Stacey, R. (2007). Strategic management and organizational dynamics: The challenge of complexity to ways of thinking about organizations (5th ed.). Harlow, England; New York: Financial Times Prentice Hall.

Tam, A. C. F. (2015). The Role of a Professional Learning Community in Teacher Change: A perspective from beliefs and practices. Teachers and Teaching: Theory and Practice, 21(1), $22-43$.

Tarus, J., Gichoya, D., Muumbo, A., Henderson, S., McGreal, R., \& Conrad, D. (2015). Challenges of Implementing E-Learning in Kenya: A Case of Kenyan Public Universities. International Review of Research in Open and Distributed Learning, 16(1), 120-141.

Thieman, G. Y. (2008). Using technology as a tool for learning and developing 21 st century citizenship skills: An examination of the NETS and technology use by preservice teachers with their K-12 students. Contemporary Issues in Technology and Teacher Education, 8(4), 342-366.

University Grants Committee. (2016). Guidance Notes on Funding Scheme for Teaching and Learning Related Proposals in the 2016-19 Triennium. SAR Government. Retrieved from May 9 , 2018 , from http://www.ugc.edu.hk/doc/eng/ugc/activity/teach/triennium1619/triennium1619_gn.pdf Vargas, N. (2013). E-Learning: Much more than a matter of technology. International Journal of E-education, E-business, E-management and E-learning, 3(3), 277-284.

Venkatesh, V., \& Davis, F. D. (2000). A theoretical extension of the technology acceptance model: Four longitudinal field studies. Management Science, 46 (2), 186-204.

Zulfiqar, A. S., Fahad, A. S., \& Siraj, M. P. (2018). Factors affecting Successful Implementation of eLearning: Study of Colleges and Institutes Sector RCJ Saudi Arabia. International Journal of Emerging Technologies in Learning, 13(6), 223-230. 